\title{
Prevalence of hepatitis-B surface antigen among blood donors and human immunodeficiency virus-infected patients in Jos, Nigeria
}

\author{
CJ Uneke/ ${ }^{+}$, 0 O gbu, PU Inyama*, GI Anyanwu*, MO Njoku**, JH Idoko***
}

\begin{abstract}
Department of Medical Microbiology, Faculty of Clinical Medicine, College of Health Sciences, Ebonyi State University, PMB 053, Abakaliki, Nigeria *AIDS/Leishmaniasis Research Laboratory, Department of Zoology, University of Jos, Nigeria **GEDE AIDS \& Infectious Diseases Research Institute, Maitama Abuja, Nigeria ***Department of Medical Microbiology, Jos University Teaching Hospital, Jos, Nigeria
\end{abstract}

\begin{abstract}
Information is very scarce on the prevalence of hepatitis- $B$ virus (HBV) infection among blood donors and patients with human immunodeficiency virus (HIV) infection in Nigeria. Hepatitis-B surface antigen (HBsAg) ELISA was used to determined the prevalence of HBsAg among 175 blood donors (aged 20-40 years) and $490 \mathrm{HIV-infected}$ patients (aged 17-60 years) in Jos, Nigeria. Twenty-five (14.3\%) of the blood donors and 127 (25.9\%) of the HIVinfected individuals were HBsAg seropositive, indicating a higher HBV infection among HIV-infected persons than among healthy blood donors. A slightly higher HBsAg seroprevalence was recorded in the males (14.6\%) than females (12.9\%) of the blood donors. Among the HIV-infected patients, the males had considerably higher HBsAg seroprevalence than the females (31.8 vs 22.1\%) with the highest prevalence of HBsAg occurring in the 51-60 years age group (44\%), followed by those of 31-40 years (28.2\%). Results confirmed the high endemicity of HBV infection in Jos, Nigeria and the significantly greater prevalence of HBV infection among HIV -infected patients than among blood donors.
\end{abstract}

Key words: hepatitis B virus - human immunodeficiency virus - blood donor - prevalence

Hepatitis B virus (HBV) is the most common cause of serious liver infection in the world. It is estimated that worldwide more than two billion people have been infected by HBV and 350 million people have chronic infection (Drosten et al. 2004). The HBV, highly contagious and relatively easy to transmit from one infected individual to another, by blood-to-blood contact, during birth, unprotected sex, and by sharing needles, has relatively higher prevalence in the tropics (Finlayson et al. 1999).

Nigeria is classified among the group of countries highly endemic for HBV infection. About $75 \%$ of the Nigerian population is reportedly likely to have been exposed to HBV at one time or the other in their life (Sirisena et al. 2002). There is a high level of occurrence of blood demanding health conditions in many parts of sub-Saharan Africa. In Nigeria the increase in road accidents, pregnancy-related hemorrhage, armed robbery attacks, and violent events, increase the possibility of the transmission of HBV (and other blood-borne pathogens) through contaminated blood as reported by United $\mathrm{Na}$ tions System in Nigeria (UNSN 2001).

Coinfection with HBV and human immunodeficiency virus (HIV) is a rapidly growing public health concern. The sub-Saharan Africa has been most severely affected by the HIV/AIDS pandemic with almost $9 \%$ of its adult population living with HIV (WHO 2003). The HIV/AIDS epidemic in Nigeria has extended beyond the commonly

${ }^{+}$Corresponding author. E-mail: unekecj@yahoo.com Received 28 July 2004

Accepted 3 January 2005 classified high-risk groups and is now common in the general population with the adult prevalence rate at $5.8 \%$ in 2001 as reported by Federal Ministry of Health Nigeria (2003). The report also indicated that some parts of the country were worse affected than others but no state is unaffected. All the states of Nigeria have general population epidemics of over $1 \%$ with some areas having prevalence higher than $10 \%$. Furthermore, the infection cuts across both sexes and all age groups but youths between the ages 20-29 years are more infected. According to UNAIDS (2000), the HIV prevalence rate among Nigerian girls (15-24 years) by the end of 1999, was in the range of 4.35 to 5.89 compared to boys to 1.68 to 3.35 in the same age range.

Information is very scarce on the prevalence of $\mathrm{HBV}$ among healthy blood donors and patients with HIV infection in Nigeria. As a result of this dearth of information, guidelines, and other adequate information on the preventive and control measures are essentially lacking in many settings in Nigeria. Our objective therefore was to determine the prevalence of HBV infection among voluntary blood donors and HIV-infected individuals using HBsAg serological assay, with the view to establishing effective guidelines on the prevention and control of HBV infection in this part of the globe.

This study was part of preliminary investigation leading to advanced research on HBV and HIV coinfection in Nigeria.

\section{MATERIALSAND METHODS}

Study area - The study was conducted from December 1999 through May 2002 in Jos, located in an area covering about $9400 \mathrm{~km}^{2}$ of the crystalline complex in North- 
central Nigeria. Its average elevation is about $1250 \mathrm{~m}$ above mean sea level and has an average annual rainfall of about $1100 \mathrm{~mm}$. Large numbers of people from many other parts of the country and foreigners alike have been attracted to the area purely to exploit its economic viability, consequently the area is reported to have the highest prevalence of sexually transmitted diseases particularly HIV infection (Federal Ministry of Health Nigeria 2003). There is also an unprecedented rise in the number of intravenous drug users (IDUs) especially among students of secondary and tertiary institutions in the region as reported by UNSN (2001).

HIV-infected patients - Individuals who visited Jos University Teaching Hospital (JUTH) and Plateau Specialist Hospital (PSH) from December 1999 through May 2002 who had symptoms suspected to be retroviral in nature were considered for the study. Majority of these individuals were in their third and fourth decades of life and were mostly females. In Nigeria more females than males visit hospitals for medical attention. With the assistance of these patients' physicians informed consent was obtained for each patient with the assurance that all information obtained would be treated with utmost confidentiality and for the purpose of research work only. Thereafter, about $4 \mathrm{ml}$ of blood sample was obtained by venepuncture from each of these patients and serum separated for HIV screening. After the screening of these patients numbering 852 , the HIV serostatus of 490 of them (aged 17-60 years) was confirmed by immunoblot analysis using a commercially available kit (Bio-Rad, Novapath Diagnostic Group, US), at the International Centre for Scientific Culture (ICSC) Retroviral Laboratory, PSH, Jos. This was after an initial HIV screening using the vironostica ${ }^{\circledR}$ HIV-1 microelisa system, also commercially available (Organon Teknika, Durham, US) at AIDS/Leishmaniasis Research Laboratory, University of Jos. The 490 patients constituted the HIV-infected population.

Blood donors - One hundred and seventy five individuals who visited the blood bank unit of JUTH for voluntary donation of blood between December 1999 and May 2002 were enrolled in the study. Before inclusion into the study population, each donor's HIV-serostatus was determined. This was the number one pre-requisite for blood donation at the hospital. Hence the 175 individuals enrolled were HIV-negative. The second inclusion criterion was that the donor never had any infection in the last 3 months prior to blood donation. Finally, each one of them was certified healthy by a physician. The age range was $20-40$ years with mean age at 28.5 years. Donors were mostly young men making up $82.3 \%$ of the donors. All the patients were informed verbally and their consent duly obtained. About $4 \mathrm{ml}$ of venous blood was obtained from each subject, serum separated and stored at $-20^{\circ} \mathrm{C}$ until assayed.

Hepatitis B surface antigen (HBsAg) assay - The 490 and 175 serum samples from the HIV-seropositive individuals and blood donors respectively were assayed for HBsAg by commercially availably enzyme-linked immuosorbent assay kit (Murex Diagnostics Ltd., Dartford, UK) at the AIDS/Leishmainasis Research Laboratory University of Jos. Manufacturer's instruction were strictly followed to determine the HBsAg seropostivity or otherwise of each serum sample.

\section{RESULTS}

Of the 175 donors screened, 25 (14.3\%) were seropositive for HBsAg. The prevalence of HBsAg was slightly higher in the males $(14.6 \%)$ than female $(12.9 \%)$ among the blood donors (Table I). Individuals of age group 20-30 years had higher prevalence of HBsAg than those of 3140 years.

Among the HIV-infected patients 127 (25.9\%) out of the 490 individuals screened were seropositive for HBsAg. The prevalence of HBsAg seropositivity was considerably higher in the males (31.8\%) compared to the females (22.1\%) among individuals infected with HIV (Table II). However, overall total indicated that individuals of age group 51-60 years had the highest prevalence HBsAg (44\%) followed by those of 31-40 years age group (28.2\%).

\section{DISCUSSION}

The classification of high endemicity for HBV has been defined as HBsAg greater than $7 \%$ in an adult population (Hodges et al. 1998). The HBsAg seropositivity of $14.3 \%$ among blood donors and $25.9 \%$ among HIV-infected patients confirmed that Jos, Nigeria is still endemic for HBV infection. Our results were in conformity with earlier reports from community and hospital based studies in some parts of Nigeria, which showed high prevalence HBsAg ranging from 7.4-26\% (Ekpo et al. 1995).

In this study, our findings indicated that HBsAg seropositivity was greater among HIV-infected patients than among blood donors. This is consistent with findings of Treitinger et al. (2004) from Florianópolis-Brazil where $18.9 \%$ of HIV-infected persons and $0.7 \%$ of blood donors

TABLE I

Prevalence of hepatitis B surface antigens (HBsAg) among blood donors in Jos, Nigeria

\begin{tabular}{|c|c|c|c|c|c|c|}
\hline \multirow[b]{2}{*}{$\begin{array}{l}\text { Age } \\
\text { (years) }\end{array}$} & \multicolumn{2}{|c|}{ Male } & \multicolumn{2}{|c|}{ Female } & \multicolumn{2}{|c|}{ Overall total } \\
\hline & $\begin{array}{c}\mathrm{Nr} \\
\text { screened }\end{array}$ & $\begin{array}{c}\mathrm{Nr}(\%) \text { with } \\
\text { HBsAg }\end{array}$ & $\begin{array}{c}\mathrm{Nr} \\
\text { screened }\end{array}$ & $\begin{array}{c}\mathrm{Nr}(\%) \text { with } \\
\text { HBsAg }\end{array}$ & $\begin{array}{c}\mathrm{Nr} \\
\text { screened }\end{array}$ & $\begin{array}{c}\mathrm{Nr}(\%) \text { with } \\
\text { HBsAg }\end{array}$ \\
\hline $20-30$ & 98 & $16(16.3)$ & 18 & $3(16.7)$ & 116 & $19(16.4)$ \\
\hline $31-40$ & 46 & $5(10.9)$ & 13 & $1(7.7)$ & 59 & $6(10.2)$ \\
\hline Total & 144 & $21(14.6)$ & 31 & $4(12.9)$ & 175 & $25(14.3)$ \\
\hline
\end{tabular}


TABLE II

Prevalence of hepatitis B surface antigens (HBsAg) among human immunodeficiency virus-infected patients in Jos, Nigeria

\begin{tabular}{|c|c|c|c|c|c|c|}
\hline \multirow[b]{2}{*}{$\begin{array}{l}\text { Age } \\
\text { (years) }\end{array}$} & \multicolumn{2}{|c|}{ Male } & \multicolumn{2}{|c|}{ Female } & \multicolumn{2}{|c|}{ Overall total } \\
\hline & $\begin{array}{c}\mathrm{Nr} \\
\text { screened }\end{array}$ & $\begin{array}{c}\mathrm{Nr}(\%) \text { with } \\
\text { HBsAg }\end{array}$ & $\begin{array}{c}\mathrm{Nr} \\
\text { screened }\end{array}$ & $\begin{array}{c}\mathrm{Nr}(\%) \text { with } \\
\text { HBsAg }\end{array}$ & $\begin{array}{c}\mathrm{Nr} \\
\text { screened }\end{array}$ & $\begin{array}{c}\mathrm{Nr}(\%) \text { with } \\
\text { HBsAg }\end{array}$ \\
\hline$\leq 20$ & 6 & $2(33.3)$ & 9 & $2(22.2)$ & 15 & $4(26.7)$ \\
\hline $21-30$ & 35 & $12(34.3)$ & 149 & $28(18.8)$ & 184 & $40(21.7)$ \\
\hline $31-40$ & 86 & $24(27.9)$ & 101 & $29(28.7)$ & 188 & $53(28.2)$ \\
\hline $41-50$ & 46 & $14(30.4)$ & 33 & $5(15.2)$ & 78 & $19(24.4)$ \\
\hline $51-60$ & 19 & $9(47.4)$ & 6 & $2(33.3)$ & 25 & $11(44.0)$ \\
\hline Total & 192 & $61(31.8)$ & 298 & $66(22.1)$ & 490 & $127(25.9)$ \\
\hline
\end{tabular}

were HBsAg seropositive. This is not unexpected as Fauci and Lane (1998) showed that HIV infection has several effects on HBV infection and is associated with approximately a threefold increase in the development of persistent hepatitis B surface antiginemia. This may have accounted for the higher prevalence of HBsAg among the HIV-infected patients.

Analysis of sex-related seroprevalence of $\mathrm{HBsAg}$ showed that the males were more infected than the females. The difference was only slight among the blood donors but considerable in the HIV-infection population although no statistically significant difference was observed. In Nigeria multiple sexual partnerships and promiscuity are habits occurring with higher frequency among males than females as indicated by UNSN (2001). This may explain the higher rate of HBsAg seroprevalence among the male population.

Studies have shown that the likelihood of chronicity after acute HBV infection varies as a function of age in both immunocompetent and immuno-compromised hosts (Dienstag \& Isselbacher 1998). In this study higher HBsAg seroprevalence was observed among the 20-30 years age category of the blood donors. This could be associated with sexual activity and intravenous drug use reported to be highest among Nigerians in their third decade of life (UNSN 2001). Among the HIV-infected patients, HBsAg prevalence was highest in the 51-60 years age group. The reason for this was not immediately apparent. However reviews by Fauci and Lane (1998) and Osmond (1994) in different transmission groups confirmed that age is a cofactor for HIV disease progression, with the older age groups more likely to develop HIV/AIDS related disorders.

In conclusion, this study has provided additional information on the burden of HBV infection in Jos, Nigeria. The use of other HBV infection serological markers such as anti-HBs, anti-HBc, HBeAg, and anti-HBe is advocated for future studies. A case is made for further investigations at immunological and molecular levels to elucidate the interaction of HBV and HIV coinfection in this part of the globe.

\section{ACKNOWLEDGEMENT}

To the management to Jos University Teaching Hospital and Plateau Specialist Hospital both in Jos, for logistical support. To the technical assistance of Mr Jelpe Dadik of International Center for Scientific Culture Laboratory. To Dr SM Agwale Director, GEDE AIDS/Infectious Diseases Research Institute Abuja for donating the HIV kits used.

\section{REFERENCES}

Dienstag JL, Isselbacher KJ 1998. Chronic hepatitis. In AS Fauci, E Braunwald, KJ Isselbacher (eds), Harrison's Principles of Internal Medicine, Vol. 1, 14 th ed., Mc-GrawHill, New York, p. 1696-1704.

Drosten C, Nippraschk T, Manegold C, Meisel H, Brixner V, Roth WK, Apedjinou A, Gunther S 2004. Prevalence of hepatitis B virus DNA in anti-HBC-positive/HBsAg-negative sera correlates with HCV but not HIV serostatus. J Clin Virol 29: 59-68.

Ekpo M, Sasegbon H, Oyewole F 1995. HIV and HBV serostatus of non- intravenous drug users in Lagos, Nigeria. Nig Med J 29: 35-36.

Fauci AS, Lane HC 1998. Human immunodeficiency virus (HIV) disease: AIDS and related disorders. In AS Fauci, E Braunwald, KJ Isselbacher (eds), Harrison's Principles of Internal Medicine, Vol. 1, 14 th ed., Mc-Graw-Hill, New York, p. 718-724.

Federal Ministry of Health Nigeria 2003. National HIV/AIDS and Reproductive Health Survey, Abuja, 209 pp.

Finlayson MDC, Hayes PC, Simpson KJ 1999. Diseases of the liver and biliary system: hepatitis. In C Haslett, ER Chilvers, JAA Hunter (eds), Davidson's Principles and Practice of Medicine, Churchill Living Stone, London, p. 706-715.

Hodges M, Sanders E, Aitken C 1998. Seroprevalence of hepatitis markers: $\mathrm{HAV}, \mathrm{HBV}, \mathrm{HCV}$, and $\mathrm{HBV}$ amongst primary school children in Freetown Sierra Leone. W Afr J Med 17: 3-7.

Osmond DH 1994. HIV disease progression from infection to CDC defined AIDS. In PT Cohen, MA Sande, PA Volberding (eds), The AIDS Knowledge Base, Little Brown, New York, p. 1.7: 11-1.7:19. 
Sirisena ND, Njoku MO, Idoko JA, Isamade E, Barau C, Jelpe D, Zamani A, Otowo S 2002. Carriage rate of hepatitis-B surface antigen (HbsAG) in an urban community in Jos, Plateau State, Nigeria. Nig Postgrad Med J 9: 7-10.

Treitinger A, Spada C, Ferreira LA, Neto MS, Reis M, Verdi JC, de Miranda AF, de Oliveira OV, Van der Sander SM, Abdalla DS 2004. Hepatitis B and hepatitis C prevalence among blood donors and HIV-1infected patients in
Florianopolis, Brazil. Braz J Infect Dis 4: 192-196.

UNAIDS 2000. Report of the Global HIV/AIDS Epidemics, Geneva.

UNSN 2001. Nigerian Common Country Assessment, World Health Organization, Geneva, 563 pp.

WHO 2003. Global Health-sector Strategy for HIV/AIDS 2003-2007, Geneva, 32 pp. 